\title{
HL-A 27 and acute anterior uveitis
}

\author{
* R. MAPSTONE AND $\dagger J$. G. WOODROW \\ From * St Paul's Eye Hospital, Liverpool, and $\uparrow$ Nuffield Unit of Medical Genetics, Department of Medicine, University \\ of Liverpool
}

The presence of the histocompatibility antigen HL-A 27 in approximately 90 per cent of patients with ankylosing spondylitis (Brewerton, Caffrey, Hart, James, Nicholls, and Sturrock, I973a; Schlosstein, Terasaki, Bluestone, and Pearson, I973) led Brewerton, Caffrey, Nicholls, Walters, Oates, and James (1973b) to investigate its presence in patients with anterior uveitis. They found the antigen in 26 of 50 patients with anterior uveitis, in eight of whom there was no associated systemic disease. A similar incidence was found by Mapstone and Woodrow (1974)-32 of 59 patients, in 17 of whom there was no systemic disease. The anteior uveitis syndrome associated with the presence of the HL-A 27 antigen, and the implications of this relationship for the aetiology of anterior uveitis are described in this paper.

\section{Material and methods}

One hundred patients with acute endogenous anterior uveitis were referred to the uveitis clinic and carefully documented throughout the course of the attack. Particular attention was paid to the following:

I. Duration (that is time interval) between onset of symptoms and clinical quiescence.

2. Presence of cells in anterior vitreous.

3. Amount of mechanical ptosis.

4. Presence of an exudate in anterior chamber.

5. Nature of keratic precipitates.

6. Intraocular pressure.

Inquiry as to previous episodes of uveitis was made and details of rheumatic, skin, and other symptoms recorded. Where relevant the skin and joints were examined. A routine $x$-ray of chest and sacroiliac joints was carried out with further appropriate $x$ rays being taken when indicated.

HL-A typing of leucocytes was carried out on each patient using the 2-stage lymphocytotoxicity micromethod (Terasaki and McGlelland, 1964). The panel of sera used to test for HL-A 27 included three which were considered monospecific. (The detailed typing and comparison with controls will be published elsewhere, Woodrow, Mapstone, Anderson, and Usher, 1975.)

\section{Results}

Of the roo patients, go had a non-granulomatous and ro a granulomatous type of uveitis.

Address for reprints: R. Mapstone, St Paul's Eye Hospital, Liverpool L3 9PF

\section{Non-granulomatous anterior uveitis (NGAU)}

$5^{\mathrm{I}}$ were men and 39 women. Table I shows that $5 \mathrm{I}$ of the 90 patients $(55.7$ per cent) had the HL-A 27 antigen. The incidence was 58.8 per cent in men and 53.8 per cent in women. The incidence in 233 controls was $8 \cdot 2$ per cent. It is seen that evidence of associated systemic disease was commoner in men.

Table I Sex and age of $9 \circ$ patients with NGAU and presence of systemic disease according to presence of $H L-A 27$ antigen

\begin{tabular}{|c|c|c|c|c|}
\hline$H L-A 27$ antigen & \multicolumn{2}{|c|}{ Positive } & \multicolumn{2}{|c|}{ Negative } \\
\hline No. of cases & \multicolumn{2}{|c|}{$5^{1}$} & \multicolumn{2}{|c|}{39} \\
\hline \multirow[t]{2}{*}{ Sex } & M & $\mathbf{F}$ & $\mathbf{M}$ & $\mathbf{F}$ \\
\hline & 30 & $2 \mathrm{I}$ & 21 & I 8 \\
\hline Mean age (years) & $4 \mathrm{I} \cdot 8$ & $4^{2 \cdot 6}$ & $44^{\cdot 2}$ & $42 \cdot 7$ \\
\hline Systemic disease & 18 & 5 & 4 & I \\
\hline
\end{tabular}

Table II records the associated systemic diseases found. Of I 3 patients with ankylosing spondylitis I I were HL-A 27 positive and, of the two who were negative, one had ulcerative colitis. All but one of the patients with sacroiliitis or Reiter's syndrome were HL-A 27 positive. All five patients with psoriasis (of whom two had ankylosing spondylitis and one had had Reiter's syndrome) were positive.

In Table III the frequencies of five salient clinical features are recorded, together with the percentage in each group that were HL-A 27 positive. Thus the presence of an exudate made it highly probable that the patient was HL-A 27 positive. The incidence of HL-A 27 in relation to the number of these features present in each individual patient is shown in Table IV.

Finally Table V records the salient data for the 28 patients who were HL-A 27 positive but had no evidence of systemic disease.

\section{Granulomatous anterior uveitis $(G A U)$}

All ro patients in this group were HL-A 27 negative. 
Table II Details of systemic diseases in 28 patients according to sex and presence of $H L-A 27$ antigen

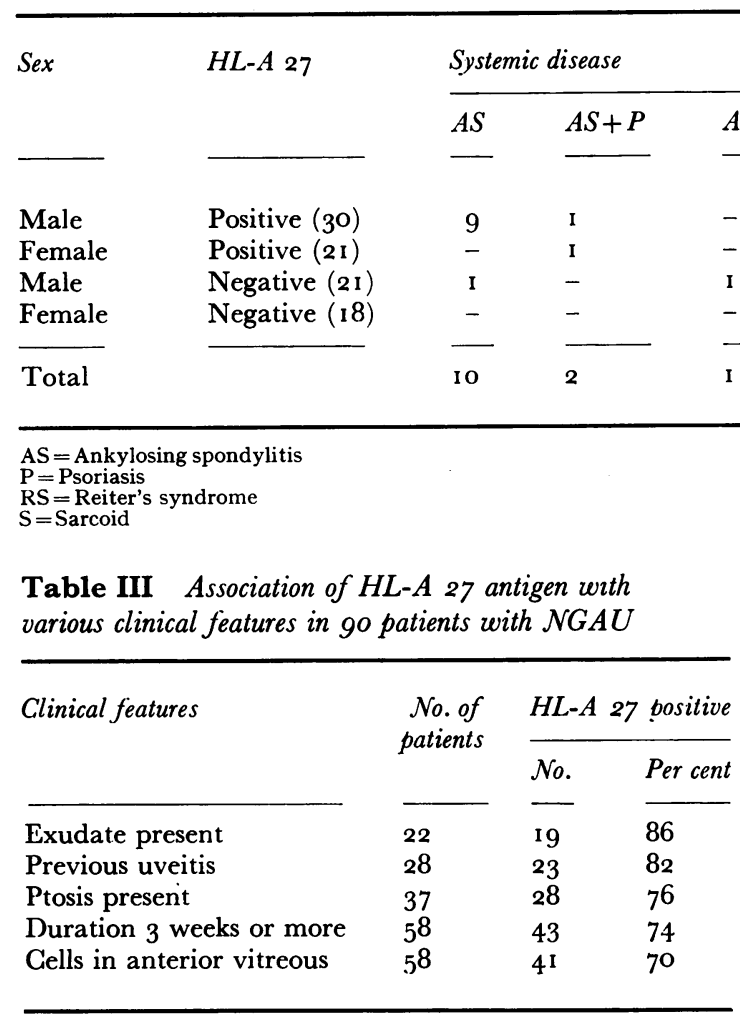

Table IV Incidence of $H L-A 27$ according to number of clinical features (see Table III) present in the individual patient

\begin{tabular}{lcccc}
\hline & & \multicolumn{2}{c}{$H L-A$} & 27 positive \\
\cline { 4 - 5 } $\begin{array}{l}\text { No. of clinical } \\
\text { features }\end{array}$ & No. of patients & & No. & Per cent \\
\cline { 3 - 5 } \cline { 4 - 5 } & & & & \\
5 or more & 6 & 6 & 100 \\
3 or more & 24 & 22 & 95 \\
2 or more & 43 & 36 & 86 \\
& 58 & 44 & 75 \\
\hline
\end{tabular}

Some details in regard to these patients are shown in Table VI. One patient had sarcoidosis. Six of these patients had a mild or minimal degree of injection, all showed mutton fat keratic precipitates, the latter being the last sign to disappear in five patients.

\section{Discussion}

The subdivision of acute anterior uveitis into granulomatous and non-granulomatous is somewhat arbitrary

$\mathrm{SI}=$ Sacroiliitis

$\mathrm{UC}=$ Ulcerative colitis

Number in parentheses is the total number in each category

Table V Details of $28 \mathrm{HL}-\mathrm{A} 27$ positive patients with no evidence of systemic disease

\begin{tabular}{|c|c|c|c|}
\hline \multicolumn{2}{|l|}{ Sex } & Male & Female \\
\hline \multirow{3}{*}{\multicolumn{2}{|c|}{$\begin{array}{l}\text { No of cases } \\
\text { Mean age (years) } \\
\text { Past uveitis }\end{array}$}} & 12 & 16 \\
\hline & & $37^{\cdot} 2$ & $4^{1 \cdot 7}$ \\
\hline & & 4 & 4 \\
\hline \multirow{4}{*}{$\begin{array}{l}\text { No. of } \\
\text { features } \\
\text { (Table III) }\end{array}$} & 5 & I & 2 \\
\hline & 4 or more & 5 & 7 \\
\hline & 3 or more & 8 & 9 \\
\hline & 2 or more & I I & IO \\
\hline
\end{tabular}

Table VI Detalls of Io patients with granulomatous uveitis

\begin{tabular}{|c|c|c|c|}
\hline Sex & & Male & Female \\
\hline $\begin{array}{l}\text { No. of cases } \\
\text { Mean age (years) } \\
\text { Systemic disease }\end{array}$ & & $\begin{array}{c}5 \\
37 \cdot 4 \\
-\end{array}$ & $\begin{array}{l}5 \\
43 \cdot 2 \\
\text { I (sarcoid) }\end{array}$ \\
\hline $\begin{array}{l}\text { No. of } \\
\text { features } \\
\text { (Table III) }\end{array}$ & $\begin{array}{l}5 \text { or more } \\
4 \text { or more } \\
3 \text { or more } \\
2 \text { or more }\end{array}$ & $\begin{array}{r}- \\
\\
3\end{array}$ & $\begin{array}{l}- \\
\mathbf{I} \\
3 \\
5\end{array}$ \\
\hline
\end{tabular}

but clinically useful. The criterion used here was the presence or absence of mutton fat KP, and in the context of this paper, the ro patients showing these formed a fairly homogenous group which is not associated with the presence of the HL-A 27 antigen.

NGAU again forms a clinically homogenous group with gradation of clinical intensity from mild 
to severe. In a previous paper (Mapstone, 1968) it was shown that the more intense the inflammation the higher was ipsilateral corneal temperature and that duration of inflammation had a highly significant positive linear correlation to corneal temperature increase. It was also shown (Mapstone, 197I) that severe inflammations were associated with cyclitic involvement, which implies cells in the anterior vitreous, a mechanical ptosis, and exudate. Using these criteria plus a history of uveitis, any one attack of NGAU can be judged as being associated with the presence of HL-A 27 with a probability of 0.8 , on clinical grounds alone (Tables III, IV). In addition, the more severe the inflammation, the greater was the probability of relevant associated systemic disease.

The clinical syndrome associated with the HL-A 27 antigen has therefore the following characteristics: Unilateral inflammation occurs in a preponderance of males (male: female ratio, $3: 2$ ) exhibiting a mechanical ptosis, and a painful, diffusely red, photophobic, and lacrimating eye-a combination which makes examination difficult.

Symptoms and signs pursue a variable course with exacerbations and remissions, but generally last longer than three weeks (84 per cent).

Keratic precipitates are never mutton fat, they are usually monocellular but may become conglomerate in part or in toto.

Protein extravasation into the aqueous is always considerable and not uncommonly produces a heavy flare with exudate (37 per cent).

Posterior uveal involvement rarely occurs (2 patients) and cyclitic involvement is reflected in intraocular pressure variations which are not peculiar to this group.

There is a tendency to recurrence and 45 per cent give a past history of uveitis.

Finally, investigations reveal (significant) associated systemic disease in 60 per cent of men and 24 per cent of women.

Whilst this is the characteristic syndrome, it is not restricted to the HL-A 27 positive group. Tables III and IV show that 20 per cent of HL-A 27 negative NGAU have some of the characteristics of the positive group. Hence NGAU presents a gradation of severity from mild to severe with the majority of HL-A 27 positive patients lying at the upper end, decreasing in a linear fashion as the severity decreases. In fact, if the percentage probability of the 90 patients having the HL-A 27 antigen is plotted against their features score (that is the number of the five features shown in Table IV), then the resulting graph (see Figure) approximates to a straight line with equation $y=$ $16 x+20$, where $y$ is the probability of being HL-A 27 positive and $x$ is the clinical features score. For example, if a particular case of NGAU lasted more than 3 weeks, had a history of anterior uveitis, and cells in the anterior vitreous, the probability of 27 antigen being present would be 0.68 . If there was also an exudate the probability would increase to 0.84 .

Table $\mathrm{V}$ gives the details of the HL-A 27 positive patients with no systemic disease. There is a roughly equal sex incidence but six of the female patients had a relatively mild inflammation with a clinical features score of I or $\mathrm{o}$. Reference to Table IV shows that only

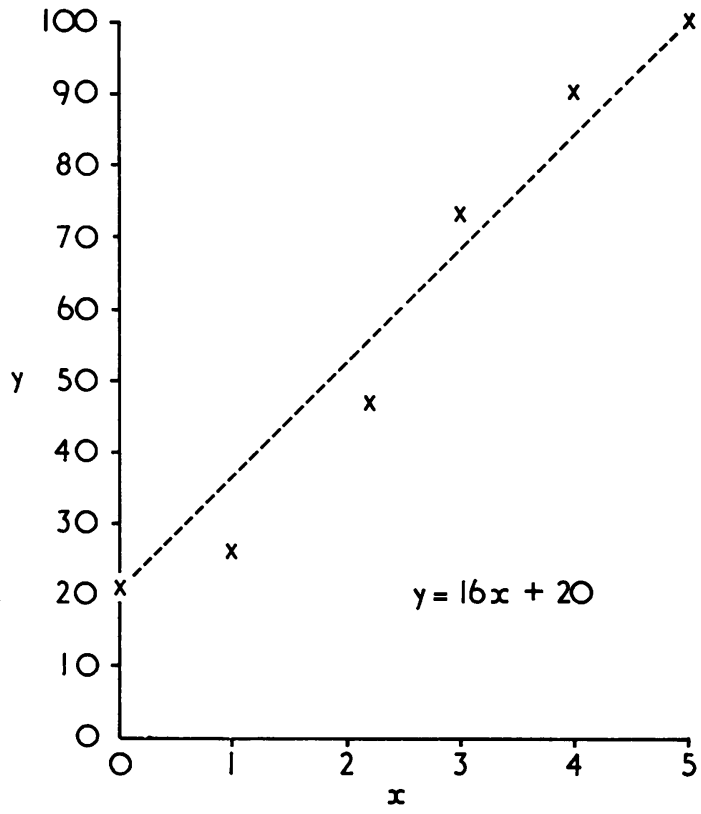

FIGURE Plot of percentage probability ( $y$ ) of having the HL-A 27 antigen against clinical features score $(x)$, see text

seven of the 5I HL-A 27 positive patients had so low a score. The seventh was, in fact, one of the 12 males shown in Table $\mathrm{V}$.

At a clinical level the association of acute nongranulomatous uveitis with ankylosing spondylitis (AS) is well established. The incidence of AS in men with acute anterior uveitis has been variously reported as 30.8 per cent (Stanworth and Sharp, 1956); 37.5 per cent (Lenoch, Králík, and Bartǒs, I959); 18 per cent (Perkins, I96I); 4I per cent (Haarr, I960). I 7 per cent of women with anterior uveitis were reported to have evidence of AS (Haarr, 1960). Conversely it has been found that 17 to 30 per cent of patients with AS gave a history of uveitis, the incidence varying with the duration of spinal disease (Wilkinson and Bywaters, 1958). In four out of 222 patients the uveitis was the first clinical manifestation, preceding evidence of spondylitis by I to 9 years. Romanus (19.53) reported the overall incidence of uveitis in I I 7 patients with AS to be 28 per cent and it was the presenting feature in seven cases.

In relation to Reiter's syndrome (RS), Perkins 
( $196 \mathrm{I}$ ) reported as many as 28 per cent of men with anterior uveitis to have had RS. Conversely Hancock ( 1960$)$ reported that an episode of uveitis was a feature of the history in 37 per cent of patients who had had RS. Popert, Gill, and Laird (1964) described uveitis as being a rare manifestation during the acute episode of RS but the incidence increased with the duration of follow-up after the first attack. Although the relatively high incidence in these studies may reflect selection bias it is evident that acute anterior uveitis is one of a group of diseases that occur alone or in various combinations, and it is now evident that a genetically-determined susceptibility underlies this group. The association with HL-A 27 provides evidence for one of the genetic factors which is operating. Of particular interest is that, of the 63 patients in the present study who had no evidence of systemic disease, 28 ( 12 men, 16 women) were HL-A 27 positive. Thus it seems likely that in many, if not most, of these 63 patients the aetiology of the uveitis is similar to that seen in the group in which rheumatic disease is present.

HL-A specificities form a polymorphic series determined by alleles at two closely-linked loci. They represent small differences in the chemical configuration of glycoproteins within the plasma membranes of all nucleated cells. In considering possible ways in which susceptibility to this group of diseases might be associated with the HL-A phenotype, two main lines of argument can be put forward.

First, it is possible that the actual structural configuration of the HL-A 27 determinants on cell surfaces could have a direct influence in that there may be structural similarity to antigenic determinants on the surface of an infective agent, bacterial or viral. This on the one hand could lead to impairment of the immune response to such infection and its pathogenicity would be enhanced. On the other hand such 'molecular mimicry' could result in serological cross-reactivity between HL-A 27 and such agents, and any antibody formed might give rise to immune complexes with free HL-A antigen. It is also possible that cell surface receptors for virus attachment might be influenced by the HL-A phenotype.

Secondly, there is good reason to suspect from studies of the homologous $\mathrm{H}-2$ system in the mouse (Bach, 1972) that there probably exist, closely associated with the HL-A chromosomal region in man, loci at which the determination of specific immune responses occur. It can be envisaged that an allele or alleles at such loci might determine a particular immune response to infective agents, which, in turn predisposes to the particular disease process. The implication of this would be that the association with HL-A 27 is a secondary phenomenon arising from a situation in which the relevant immune response alleles are unduly associated in the population with
HL-A 27. This would be a situation of linkage disequilibrium. That such a situation can exist is shown by the studies in respect of HL-A 3,7 and multiple sclerosis (Jersild, Fog, Hansen, Thomsen, Svejgaard, and Dupont, 1973).

The observation that there is a striking association between HL-A 27, AS, RS, and NGAU provides circumstantial evidence for a common pathogenesis. In this respect $\mathrm{RS}$ is of key importance because the syndrome is known to be precipitated by infective agents, the agents of non-specific urethritis (NSU) in most instances, dysentery in some and occasionally Yersinia enterocolitica (Ahvonen, Sievers, and Aho, I969; Solem and Lassen, I97 I). Of patients with RS 70 to 75 per cent are HL-A 27 positive (Brewerton and others, r973a; Woodrow, Treanor, and Usher, I974) and arthropathy following $r$. enterocolitica occurs particularly in HL-A 27 positive individuals (Aho, Ahvonen, Lassus, Sievers, and Tilikainen, r973). The circumstantial evidence therefore points to infective agents being important in the pathogenesis of NGAU whether or not associated rheumatic disease is present. There is little direct clinical evidence of the mechanism of the inflammatory processes in joints or eyes in the conditions under consideration but it seems that immunologically-mediated processes are important.

In relation to the pathogenesis of endogenous uveitis, a large body of experimental evidence suggests that uveitis, resembling in some respects the clinical condition, can be produced by immunological mechanisms. The production of 'endogenous uveitis' by direct introduction of heterologous antigen into the uvea and the ability to provoke secondary attacks thereafter by parenteral stimulation with antigen has been repeatedly demonstrated (Kümmell, I9I I; Foss, I949; Zimmerman and Silverstein, 1959). Provided that antigen can obtain access to the uvea in the first place, the eye appears to have a propensity to become sensitized for further immunologicallymediated inflammatory responses. Local non-specific factors such as trauma or other inflammatory episodes may facilitate sensitization (MacLean, I936; Gamble, Aronson, and Brescia, 1970). There is evidence that persistence of sensitized lymphoid cells in the uvea for long periods of time may be the basis for the ease with which systemic stimulation with antigen can lead to recurrent uveitis (Silverstein, I964). Both Arthus and delayed hypersensitivity types of immunological reaction may play a part and local formation of antibody in the uvea may be especially important in facilitating immune complex disease. However it remains to be demonstrated that these experimental systems are directly relevant to the cause of NGAU in man.

Of the group of diseases under consideration, only in Reiter's syndrome is there any good evidence for the responsible infective agents. The agent or agents 
of NSU have not been clearly defined although a Chlamydia has been isolated in 44 per cent of patients (Dunlop, Jones, Darougar, and Treharne, 1972) and evidence for chlamydial infection was obtained in 52 per cent of patients with RS (Ostler, Dawson, Schachter, and Engelman, 1971). Evidence has been put forward that a large majority of patients with AS show chronic prostato-vesiculitis (Romanus, 1953) and similarly 69 per cent of men with uveitis were found to show evidence of a similar focus of infection (Catterall, 1960).

It now seems very likely that, when more is known of the specific infective agents that initiate Reiter's syndrome and ankylosing spondylitis and of the nature of the pathogenesis of the inflammatory arthropathy involved, this information will be of great relevance to the pathogenesis of many if not most cases of NGAU.

\section{Summary}

5I (30 men and 21 women) of 90 consecutive patients with acute non-granulomatous anterior uveitis were HL-A 27 positive. This frequency of 55.7 per cent compares with 8.2 per cent in controls. Twenty-three patients ( 8 men and 5 women) had in addition evidence of systemic disease, including ankylosing spondylitis, sacroiliitis and Reiter's syndrome, sometimes associated with psoriasis. Twenty-eight of 63 patients without evidence of systemic disease were
HL-A 27 positive, suggesting that the uveitis in many of these cases has a similar aetiology to those with rheumatic disease. The uveitis associated with HL-A 27 is typically unilateral, associated with mechanical ptosis, and a painful diffusely red, photophobic, and lacrimating eye, generally lasting 3 weeks or more. Protein extravasation into the aqueous is considerable, cells are usually present in the aqueous and anterior vitreous, and keratic precipitates are never mutton fat in appearance. Recurrent episodes are characteristic.

The association with HL-A 27 suggests that many if not most cases of non-granulomatous anterior uveitis have a close aetiological relationship to ankylosing spondylitis and Reiter's syndrome and it is likely that infective agents, leading to an unusual immunologically mediated inflammatory response in predisposed individuals, are involved.

Ten patients with granulomatous anterior uveitis were HL-A 27 negative.

We are grateful to colleagues who referred patients for study. We are much indebted to the National Tissue Typing Reference Laboratory, Bristol and to Transplantation and Immunology Branch, N.I.H., Bethesda for the typing sera. The work was supported in part by the Research Committee of the United Liverpool Hospitals. Excellent technical assistance was provided by $\mathrm{Mr} \mathrm{N}$. Usher and Miss Jeanette Anderson, and we should also like to thank Miss E. Grogan for her secretarial assistance.

\section{References}

Aho, K., AHVonen, P., lassus, A., SIEvers, K., and tilikainen, A. (I973) Lancet, 2, I 57

AHVONEn, P., SIEVERs, K., and AHO, K. (I969) Acta rheum. scand., 15, 232

BACH, F. H. (1972) In 'Genetic Control of Immune Responsiveness', ed. H. O. McDevitt and M. Landy, p. I05. Academic Press, New York

BREWERTON, D. A., CAFFREY, M., HART, F. D., JAMES, D. C. O., NIGHOLLS, A., and STURROGK, R. D. (I973a)

Lancet, I, 904

-

CATterall, R. D. (i96o) Brit. F. vener. Dis. 36, 27

DUNLOP, E. M. C., JONES, B. R., DAROUgAR, S. and TREhARNE, J. D. (1972) Brit. med. J., 2, 575

FOss, B. (I949) Acta path. microbiol. scand., Suppl. 81, p. 3

Gamble, c. N., ARonson, s. B., and Brescia, F. B. (1970) Arch. Ophthal. (Chicago), 84, 32 I

HAARR, M. (1960) Acta ophthal. (Kbh.), 38, 37

HANGOCK, J. A. H. (1960) Brit. J. vener. Dis. 36, 36

JERSILD, C., FOG, T., HANSEN, G. S., THOMSEN, M., SVEJGAARD, A., and DUPONT, B. (1973) Lancet, 2 , I 22 I

KÜMMELl, R. (I II I) v. Graefes Arch. Ophthal., 79, 528

LENOCH, F., KRÁlík, v., and BARTǒs, J. (1959) Ann. rheum. Dis., 18, 45

maclean, A. L. (I936) Trans. Amer. ophthal. Soc., 34, 324

MAPSTONE, R. (1968) Brit. F. Ophthal., 52, 9 I 7

(I97I) Trans. ophthal. Soc. U.K., 91, 74I

and woodrow, J. c. (1974) Lancet, I, 68 I

ostler, H. B., DAWSON, c. R., SGhachter, J., and engleman, E. P. (1971) Amer. 7. Ophthal., 71, 986

PERKINS, E. S. (I96I) 'Uveitis and Toxoplasmosis'. Churchill, London

POPERT, A. J., GILl, A. J., and LAIRD, s. m. (1964) Brit. J. vener. Dis., 40, I6o

ROMANus, R. (1953) Acta med. scand., Suppl. 280

schlosstein, L., terasaki, P. I., Bluestone, R., and Pearson, c. m. (i973) New Engl. J. Med., 288, 704 
SILverstein, A. M. (1964) In 'Immunopathology of Uveitis', ed. A. E. Maumenee, and A. M. Silverstein. Williams \& Wilkins, Baltimore

SOlEm, J. H., and LASSEN, J. (197I) Scand. F. infect. Dis., 3, 83

STANWORTh, A. and SHARP, J. (1956) Ann. rheum. Dis., I5, I40

TERASAKI, P. I., and MCGLELLAND, J. D. (1964) Nature (Lond.), 204, 998

WiLkinson, M., and BYWATERS, E. G. L. (1958) Ann. rheum. Dis., 17, 209

WOODRow, J. C., MAPSTONe, R., ANDerson, J., and usher, N. (1975) Tissue Antigens (in press) , TREANOR, B., and USHER, N. (1974) Ibid., 4, 533

zimmerman, L. E., and silverstein, A. м. (1959) Amer. J. Ophthal., 48, 447s 